\title{
Europe as a Global Actor: The (Un)Holy Trinity of Economy, Security and Diplomacy
}

Citation for published version (APA):

Pomorska, K., \& Vanhoonacker, S. M. R. L. (2015). Europe as a Global Actor: The (Un)Holy Trinity of Economy, Security and Diplomacy. Journal of Common Market Studies, 53, 216-229. [s1]. https://doi.org/10.1111/jcms.12272

Document status and date:

Published: 01/01/2015

DOI:

10.1111/jcms.12272

Document Version:

Publisher's PDF, also known as Version of record

\section{Document license:}

Taverne

\section{Please check the document version of this publication:}

- A submitted manuscript is the version of the article upon submission and before peer-review. There can be important differences between the submitted version and the official published version of record.

People interested in the research are advised to contact the author for the final version of the publication, or visit the DOI to the publisher's website.

- The final author version and the galley proof are versions of the publication after peer review.

- The final published version features the final layout of the paper including the volume, issue and page numbers.

Link to publication

\footnotetext{
General rights rights.

- You may freely distribute the URL identifying the publication in the public portal. please follow below link for the End User Agreement:

www.umlib.nl/taverne-license

Take down policy

If you believe that this document breaches copyright please contact us at:

repository@maastrichtuniversity.nl

providing details and we will investigate your claim.
}

Copyright and moral rights for the publications made accessible in the public portal are retained by the authors and/or other copyright owners and it is a condition of accessing publications that users recognise and abide by the legal requirements associated with these

- Users may download and print one copy of any publication from the public portal for the purpose of private study or research.

- You may not further distribute the material or use it for any profit-making activity or commercial gain

If the publication is distributed under the terms of Article $25 \mathrm{fa}$ of the Dutch Copyright Act, indicated by the "Taverne" license above, 


\title{
Europe as a Global Actor: the (Un)Holy Trinity of Economy, Diplomacy and Security
}

\author{
KAROLINA POMORSKA and SOPHIE VANHOONACKER \\ Maastricht University
}

\section{Introduction}

It has become customary in recent years to start the JCMS Annual Review articles on the EU as a global actor by signalling the omnipresence of crises. The year 2014 is no different. In his contribution to this volume, Desmond Dinan even coins the expression of a more 'fractious' year than ever before. Both the international as well as the European context have indeed proven to be challenging in various respects. On the global level, the difficult transformation is ongoing and there is no consensus on the norms and rules that could govern a shared international order (Kissinger, 2014). In Europe, the annexation of the Crimean peninsula and the war in Ukraine triggered the most serious security crisis since the end of the Cold War, exposing deep dividing lines between the Member States. ${ }^{1}$ Domestically, economic recovery has been slow and the 2014 elections for the European Parliament showed an increasingly disenchanted European public giving a considerable number of votes to eurosceptic parties. ${ }^{2}$ In the world of EU external relations we observed a 'change of guard', with newcomers in the positions of Presidents of the European Council and the European Commission and High Representative/Vice President (HR/VP) from autumn 2014. For this reason, we start our contribution with a short evaluation of Ashton's term of office (December 2009 to November 2014), followed by an initial discussion on the significance of the changes in leadership for the Union's policy in the world.

As a second step, we examine three major areas in which the EU traditionally has pledged to make an 'international difference': playing the role of market actor, security actor, and diplomatic actor. We borrow this typology from Mike Smith (2012), who, reflecting on the hybridity of EU external relations, also included a fourth role of normative actor. In our view, the normative dimension pervades all three external roles performed by the EU, so we do not distinguish it here as a separate category. The concept of roles is attractive as it allows for an analysis that combines both material factors (such as institutions, procedures and resources) as well as ideational factors (images, expectations and discourses) (Smith, 2012, p. 705).

As the EU continues to be the world's biggest trading power, we begin by looking into the major developments in the field of the Common Commercial Policy (CCP), with special attention given to the negotiations of the Transatlantic Trade and Investment

\footnotetext{
${ }^{1}$ See Juncos and Whitman's contribution to this volume.

${ }^{2}$ See the contributions by Hodson, Hobolt and Benczes and Szent-Ivanyi to this volume. 
Partnership (TTIP) and the Bilateral Investment Treaty with China. Second, we analyse the EU's role in the field of the Common Security and Defence Policy (CSDP) by looking at the question of defence as well as civilian and military crisis management. In 2014, the EU was involved in 15 crisis management operations, of which the majority were mostly taking place in Africa. Third, we look into the role of the EU as a diplomatic actor and an international broker by focusing on the case of Iran, where, in 2014, the HR/VP Ashton played a key co-ordinating role in the negotiations on Teheran's controversial nuclear programme.

\section{Five Years of Catherine Ashton and the European External Action Service}

The year 2014 was the last of the five-year tenure of the first High Representative for Foreign Affairs and Security Policy, Catherine Ashton. Even though she received considerable praise in the year before her departure, largely due to perceived success in negotiations with Iran (see below), her leadership and management of the EEAS was met with harsh criticism both from the press ${ }^{3}$ and from academia (Howorth, 2011; Spence, 2012; Vanhoonacker and Pomorska, 2015). In spite of the extenuating circumstances of a challenging international context and having to build up a new service from scratch, there were also considerable inherent weaknesses in the ways in which the HR/VP and the EEAS functioned.

Five years ago, in their contribution to the Annual Review, Allen and Smith (2010, p. 205) wondered whether the changes introduced by the Lisbon Treaty would provide the basis for a new role of the EU in the world arena. Their previous assessments had shown that there was often much to report in terms of institutional structures but little on real policy substance. Looking back at the first years of the HR/VP and the EEAS, we see that not much has changed. The reasons for this are mixed but the attitude and actions by the Member States stand out as key. When the EU Heads of State and Government decided to give the job to Ashton in December 2009, it was clear that they did not have the ambition of nominating a strong foreign policy chief with considerable experience in foreign policy and diplomacy. Ashton confirmed this minimalist interpretation in her first public speeches, when she contrasted her own approach to that of Javier Solana, claiming she would concentrate on 'quiet diplomacy'. This, in turn, sparked a debate among practitioners and observers with the central question: "why did she take this huge job, when her instinct seems to be to make it as low key as possible?' 4 At the time of writing in 2015, we may be closer to an answer - because this is what the Member States, especially the larger ones, wanted her to do (Balfour and Raik, 2013). The benchmark was set low as far as independence from the Member States was concerned; no 'competence creep' would be tolerated (Edwards, 2013, p. 285) and competition with national diplomatic services was 'unacceptable' (Wright, 2013, p. 9; Adler-Nissen, 2013). ${ }^{5}$

The first priority that Ashton turned to was capacity-building: establishing the EEAS and having it operational. Her negotiation skills and determination led to relatively smooth and fast negotiations with the Member States and to the agreement on the Council

\footnotetext{
${ }^{3}$ The Economist, 5 February 2011; European Voice, 5 January 2012.

${ }^{4}$ The Economist, 26 January 2010.

5 On Ashton's appointment, see Barber (2010). For more on Member States and EU foreign policy see last year's Annual Review lecture: Menon (2014).
} 
framework decision outlining the EEAS organizational structure (Council of the EU, 2010). This was followed by a deal on budget and staff regulations. In the subsequent months, even years, the internal structures needed to be tried and verified, alongside the establishment of the operating procedures. Once the EEAS was set up, the HR/VP prioritized the external EU presence and her diplomatic role, such as in, for example, the negotiations with Iran or Kosovo. This prioritization, however, came at the detriment of 'putting her own house in order' and fostering the creation of an esprit de corps in the EEAS or focusing on internal agenda-setting in the Council (Vanhoonacker and Pomorska, 2013). Even in the field of external affairs, where Ashton invested more of her time and effort, there has not been any major improvement in the internal and external leadership (Vanhoonacker and Pomorska, 2015) - an opinion voiced in the Special Report of the European Court of Auditors (Court, 2014, p.26). The document also established that the EEAS chairing the Working Groups and Committees in the Council had not shown any improvement in providing a more strategic approach in comparison with the pre-Lisbon situation, when the rotating presidency was in the chair.

A more positive side of the institutional transformation took place in the EU delegations around the world. The Member States' attitudes toward the delegations proved to be, in general, more positive than those toward the HQ in Brussels (Novotna, 2014, p. 30). Even here, however, the study of delegations in Washington DC and in Moscow has shown that the Member States were 'protective of their own turf', especially in situations when they felt the delegation was trying to either push its own particular view or to speak on matters where no single position had yet been agreed upon (Maurer and Raik, 2014, p.9).

The area where we had seen a notable improvement for the better since the establishment of the EEAS is continuity (Vanhoonacker and Pomorska, 2015). The replacement of the rotating presidency by new institutional players put an end to the six-monthly stop-go process with sudden priority changes. The increased capacity through the availability of a permanent administration, both in Brussels and abroad, able to invest in developing expertise and long-term approaches to foreign policy is unquestionably an important step forward. The enduring presence of actors both at the political and administrative levels brought added value in terms of external representation and the development of long-term relations with external interlocutors.

Even though many hoped for the appointment of a more experienced successor, the post of HR/VP went again to a politician without considerable experience in the world of international politics, the Italian foreign minister Federica Mogherini. Her strongest rival, then Poland's foreign minister, Radek Sikorski, was out of the race once there was an agreement to appoint Donald Tusk as the new President of the European Council. Following the start of the Juncker Commission, it soon turned out that the new Commission president, who was very experienced in EU affairs, would try to do something about Ashton's legacy of prioritizing the position as chair of the Foreign Affairs Council over that of Commission Vice President. His expectations toward the new HR/VP were included in a mission letter addressed to Mogherini (European Commission, 2014c). Clearly, in the efforts to address the criticism toward the EEAS for not co-ordinating sufficiently its actions with the European Commission and, more broadly, to ensure the EEAS would not become a tool of the Member States, the new HR/VP, on the instructions of Commission 
president Juncker, decided to take a few significant steps. First, she left the EEAS building and relocated her office to the Berlaymont to join the other members of the College of Commissioners. Second, she appointed Stefano Marservisi, an experienced Commission official, as the head of her cabinet. Third, half of her cabinet had been recruited from the European Commission. Finally, she has, at the instigation of Juncker, reactivated the meetings of the Commissioners' Group on External Action. This task was previously very difficult to fulfil for Ashton, considering her busy agenda and the need to travel. Reacting to the calls for more coherence, the new HR/VP 'guides' the work of Commissioners responsible for European neighbourhood policy and enlargement negotiations; trade; international co-operation and development; and humanitarian aid and crisis management. It was envisaged that the group would meet once a month, which is an ambitious goal, considering the strained calendar of the High Representative (Blockmans, 2014). The task proved too difficult for the previous HR/VP, but Mogherini hoped to change that, which she also emphasized during her hearings in the European Parliament.

It is too early to tell what will be the outcomes of these decisions, but they will put to the test the relationship with the Member States, which are the driving force in foreign and security policies. Only a year after Catherine Ashton took office, it was clear that she would consolidate her activities within the Council and the EEAS (Allen and Smith, 2011), at the expense of the European Commission. Mogherini's different approach was also already clear early in her tenure. The appointment of an Italian national to the key post in foreign affairs, during a period of strained relations with Russia, proved controversial in many (especially central and eastern) European capitals. A product of a compromise, the choice of Mogherini did not ensure trust on the side of those Member States who now hope Donald Tusk will provide a 'counterbalance' with regard to the ongoing crisis beyond the EU's eastern border.

Some time ago, we pointed out considerable weaknesses in the use of the newly gained prerogative of agenda-setting (Vanhoonacker and Pomorska, 2013). This situation did not improve considerably in 2014. The HR/VP and the EEAS have been sidelined in the ongoing conflicts in EU's neighbourhood, especially the one in Ukraine. This, however, is because of the Member States' choices (sometimes resulting from accepting the preferences of their interlocutors such as Russia) to deal with the crises elsewhere. It proves once again that the EEAS for now can only be what the Member States 'make of it'. It has not developed into a strong institution, into anything akin to a foreign ministry.

There was also a change in other posts relevant to EU external relations: Donald Tusk took over the task of the President of the European Council. In his opening speech, given on 1 December 2014, Tusk said that 'Europe has to secure its borders and support those in the neighbourhood who share our values'. The first European Council summit over which he presided (18 December 2014) dealt with the new sanctions against Russia and Tusk used the opportunity to emphasize the need for a long-term strategy toward Russia. ${ }^{6}$ His calendar during the first three days in the new job was filled with foreign policy items: calling the White House; making a pro-American statement; meeting the new Afghani leadership; and having discussions with the presidents of China, Ukraine and the Nato

\footnotetext{
${ }^{6}$ The Telegraph, 19 December 2014.
} 
Secretary General. $^{7}$ A former speech writer to Herman van Rompuy, Luuk van Middelaar, suggested that Tusk might want to do for foreign affairs "what van Rompuy did for the euro' ${ }^{8}$ It is certainly too early to make any judgment at this point, but we will return to this topic in next year's Annual Review.

\section{The European Union as a Market Actor}

As the world's largest trade power, the European Union undeniably continues to occupy a key place in the international trading system, and it is well known that it uses this position to export its regulatory practices and to promote its own values in third countries (Meunier and Nicolaidis, 2011). With the rise of the emerging powers, however, the EU's long-term position is expected to become increasingly challenged. Some have argued that as a result of the changing political and economic power relations the EU's capacity to use trade as an instrument of international influence will diminish over time (McGuire and Lindeque, 2010). It is, therefore, not surprising that the EU has been exploring ways to consolidate its position. Against the background of the changing geopolitical context and the stalled Doha negotiations, the EU has in recent years increasingly resorted to the conclusion of bilateral Free Trade Agreements (FTAs), trade and cooperation agreements and association agreements. ${ }^{9}$

Despite the well-known rhetoric about multilateralism (European Security Strategy, 2003; Van Schaik and Ter Haar, 2013), the EU has continued to invest heavily in bilateral deals. An important achievement in this respect was the conclusion in September 2014 of the negotiations on the EU-Canada Comprehensive Economic and Trade Agreement, ${ }^{10}$ the first EU free trade agreement with a G8 economy. The 1500-page agreement was negotiated over a period of five years and includes, among other things, a gradual removal of customs for almost all goods, increased regulatory co-operation, the opening up of public procurement, improved protection of intellectual property rights, the streamlining of trade in services and the promotion of investment. The fully-fledged investment chapter also contains provisions on an investor-to-state dispute settlement (ISDS), which proved to be one of the more controversial stipulations of the treaty as it raised concerns that it may negatively affect governments' capacity to regulate in the public interest. The most important gains emerging from CETA are expected to come from the mutual recognition of regulations.

Following so-called 'legal scrubbing' and translation into the $24 \mathrm{EU}$ official languages, the text will be presented to the Council for approval; it also requires the formal consent of the European Parliament. The entire process is expected to take two years, taking the ratification well into 2016 or even 2017 (Bierbrauer, 2014). In parallel with CETA, the EU and Canada have also concluded a Strategic Partnership Agreement (SPA), aimed at enhancing co-operation in foreign policy and crisis management as well as in sectoral policies such as energy, justice and home affairs and education and technology.

Although Canada is only the EU's 12th most important trading partner, the agreement is not unimportant, as it is expected to serve as a template for the Transatlantic Trade and

\footnotetext{
${ }^{7}$ Bloomberg Business, 12 December 2014.

${ }^{8}$ Cited in Carnegie Europe (2014).

${ }^{9}$ See for instance the bilateral free trade agreements (FTAs), including with South Korea (2011), Columbia (2013), Peru (2013), Singapore (2013) and several countries in Central America (2013).

${ }^{10}$ «http://trade.ec.europa.eu/doclib/docs/2014/september/tradoc_152806.pdf»
} 
Investment Partnership (TTIP) with the United States. Following the launch of the negotiations in 2013, there were three major TTIP rounds in 2014. As levies on goods traded between both sides of the Atlantic are already very low, the negotiations mainly focused on regulatory co-operation and issues such as services, intellectual property rights and rules on investment and public procurement. Given the importance of the agreement, as the US is the EU's largest trading partner, the process received a lot of attention from trade unions, professional organizations and NGOs. Critical about the lack of transparency of the negotiations, opponents warned against the adoption of inferior American standards and a subordination of EU interests to US corporations. One of the most controversial provisions of the agreement is the earlier mentioned investor-to-state dispute settlement, allowing foreign companies to challenge governmental decisions that impact on their ability to make profits. With overall support of 58 per cent, a majority of European citizens in 2014 were still in favour of an extensive regional free trade agreement across the Atlantic (Eurobarometer, 2014); with, respectively, 53 and 41 per cent against, Austria and Germany were the most critical countries (Eurobarometer, 2015). However, it remains to be seen how these figures and concentration of criticism develop as the negotiations progress. In the US, at the time of writing (spring 2015), priority is being given to the Trans-Pacific Partnership Agreement (TTP), where the negotiations are reaching their final stage and where the big challenge for the Obama administration is to obtain fast-track authority from Congress. ${ }^{11}$ Negotiated among 12 countries of the Asia-Pacific region, with the US and Japan as its key players and accounting for 40 per cent of the world's GDP, ${ }^{12}$ it is one of the cornerstones of the Obama administration's economic policy. ${ }^{13}$

TTIP is a clear illustration of how trade agreements can also serve political purposes. In the light of the evolving geopolitical context and renewed tensions with Russia, the agreement is considered an instrument that can further strengthen the position of the west. The huge new market would serve as a pole of attraction for third countries, provide leverage in international trade negotiations and give a boost to the western economic model which, following the economic and financial crisis, is viewed more critically by emerging economies (Korteweg, 2015). The attraction of the agreement is well illustrated by the voices urging Brussels and Washington to become more open about possible accession or association of interested parties (Ulgen, 2014). An important concern for countries like Turkey and Norway, who heavily depend on the internal market, is that it will be difficult to 'multilateralize' the bilateral agreement once it has been concluded. It should also be an issue of further reflection for those in the UK advocating British exit from the EU.

Next to traditional partners such as Canada and the US, the EU has been investing heavily over recent years in the conclusion of trade agreements with Asia and Latin America. The obvious priority country is China, with whom the EU in November 2013 agreed upon a wide-ranging action plan for the period up to 2020 (EEAS, 2013). Although it also has a

\footnotetext{
${ }^{11}$ According to the fast-track negotiation authority or the Trade Promotion Authority (TPA), Congress can only validate international trade agreements as a package and not amend separate parts.

12 The countries in question include Australia, Brunei, Canada, Chile, Japan, Malaysia, Mexico, New Zealand, Peru, Singapore, United States and Vietnam.

${ }^{13}$ Interview with European Parliament official, 23 April 2015.
} 
political and civil society dimension, the economic pillar is clearly predominant (Smith, 2015). In 2014, the EU and China engaged in talks about a so-called bilateral investment treaty (BIT). An important objective is to provide investors with a secure legal framework and the abolition of restrictions on trade and investment. The current investment levels are very low, with only 2.1 per cent of EU Foreign Direct Investment (FDI) going to China. China only accounts for 1 per cent of EU FDI, but since 2008 the amounts that are invested have been growing rapidly, and are expected to surge further in the years to come (Meunier, 2014).

The ongoing negotiations over the EU-China BIT provide insights into both the strengths and weaknesses of EU external actorness (Meunier, 2014). The fact that, since the Lisbon Treaty, the EU has the exclusive competence to conclude international investment treaties (Art. 207, TFEU) should in principle increase its leverage over third parties, positively affect its access to attractive international markets and enhance its capacity to impose its rules and values. In practice, however, it remains to be seen whether the European Commission, representing the 28 Member States, will be able to exploit its collective bargaining power and shape the international investment regime according to its own preferences. The long legacy whereby individual Member States were concluding their own BITs cannot be swept away overnight. In addition, countries such as Germany and France have expressed fears that an EU-level agreement may be more restrictive than one concluded on a national basis, and it is tempting for China to exploit EU internal differences. A final challenge is that the EU has the legal obligation to include clauses on sustainable development, human rights and environmental protection (Art. 205, TFEU). It is well known that China is extremely reluctant to have its hands tied by all kind of conditions and will therefore not hesitate to try to exploit its preferential relations with Member States such as Germany to limit the conditionality requirements to a minimum.

Summarizing, the year 2014 has shown a very active EU in terms of 'market power', not only in traditional fields of trade in goods and services but also in areas such as intellectual property rights, regulatory matters and investment policy. As is illustrated by the TTIP negotiations with the US and the BIT discussions with China, the trend of previous years whereby there is an increasing emphasis on the conclusion of bilateral agreements continues. As shown by the parallel negotiations with both the US and China, exerting influence in a world with multiple centres of gravity is complex and requires action at several fronts at the same time.

\section{The European Union as a Security Actor}

In the area of the Common Security and Defence Policy, the year 2014 was particularly challenging for the so far mainly silent ' $\mathrm{D}$ ' in CSDP. The crisis in Ukraine more than ever brought the urgent need for a more articulated strategic direction and enhanced capabilities to the fore. It also gave a new impetus to the debate about defence spending in Europe and led some of the eastern Member States to reconsider their defence budgets. During the summer, Poland announced its plans to increase defence spending from the current 1.95 per cent to 2.0 per cent in 2016, while Latvia and Lithuania pledged to reach that level by 2020. The European Commission, through its Industry Commissioner, called for greater collaboration between Member States' defence industries, repeating the earlier appeal of the European Council, in December 2013, to develop a more integrated 
European defence technological and industrial base (EDTIB) (European Council, 2013). The defence industry also came into the spotlight with discussion on the contracts between the Russian government and some Member States, in particular France, which, as a result of the situation in Ukraine, reluctantly postponed the delivery of two Mistral-class assault ships.

The limits of the CSDP are well illustrated when comparing the EU's timid response to the crisis on its eastern border to the response given by Nato. The latter, at its summit in Wales (September 2014), promptly raised the objective of collective defence again to the top of its agenda, immediately accompanying this strategic decision with concrete measures of operationalization (North Atlantic Council, 2014). This included the adoption of a Readiness Action Plan defining measures to respond to the security challenges along Nato's borders both in the east and the south and plans for the creation of a Very High Readiness Joint Task Force (VJTF) deployable within a couple of days. Nato also has taken much more seriously the concerns of the Baltic States and Black Sea Region by responding with military training exercises in the region (Duke and Vanhoonacker, forthcoming). For the EU, so far, this type of action is simply impossible.

Still, there were also some positive developments in the field of EU security and defence. Even though the overall impact of the 2013 December summit on CSDP has so far been limited, it nevertheless led to some follow-up initiatives in 2014. They mainly concerned striving for a strategic outlook, such as the adoption of an EU Strategy for Security at Sea, the EU Cyber Defence Policy Framework and a Policy Framework for Systematic and Long-Term Defence Cooperation (CEPS, 2015, p. 5). Another initiative was related to the adoption of a European Union Maritime Security Strategy (EUMSS), which was agreed upon in June. This welcome development took place in the complex environment of maritime security, where international co-operation had been quite difficult (European Parliament, 2013, p. 92), and can be understood as a 'litmus test' for the comprehensive approach to EU's external relations (Frontini, 2014). The long-awaited update of the 2003 European Security Strategy is, however, not to be expected before the end of 2017 or even early 2018. The revised strategy is supposed to be the result of a strategic reflection process to start after mid-June 2015 and will involve not only national governments but also representatives of civil society, think-tanks and academia.

With the ongoing crises in the EU's neighbourhood both in the east and south, crisis management is also back on the EU's agenda, in spite of the earlier signs that the EU's ambitions in this field might have been buried (Smith, 2013). In 2014, the EU launched two new missions: the Advisory Mission for Civilian Security Sector Reform in Ukraine (EUAM Ukraine, July 2014-) ${ }^{14}$ and the civilian mission EUCAP Sahel Mali (April 2014-). The latter is aimed at restoring state authority in that country and complements the EU training mission for Malian armed forces (EUTM Mali, February 2013-). In addition, the EU continued to be engaged in various other countries and regions, especially in Africa. ${ }^{15}$

Within the realm of maritime security, for instance, the EU carried on with its EU NAVFOR Atalanta operation as a way to comprehensively tackle the piracy problem

\footnotetext{
${ }^{14}$ See Juncos and Whitman's contribution to this volume.

${ }^{15}$ Apart from Mali, other African countries in which the EU was involved include the Democratic Republic of Congo, Djibouti, Kenya, Libya, Niger, Seychelles, Somalia and Tanzania.
} 
on the coast of Somalia, with Germany, Italy and Spain contributing ships. The mission, ongoing since 2008, is showing results: the piracy problem is diminishing and al-Shabaab is weakening (ECFR, 2015, p. 18). In November 2014, it was prolonged for another two years. Another new development was the relocation of the EU trainers of the Maritime Security Centre-Horn of Africa (MSC-HOA), providing 24-hour monitoring of vessels passing through the strategic Gulf of Aden. While previously working in Uganda, in February they were for the first time deployed to the capital of Somalia.

Due to the dramatic worsening of the security situation in Libya, the staff of the EU Integrated Border Assistance Mission in Libya (EUBAM) was relocated from Tripoli to Tunisia in August 2014 and was subsequently downsized to 17 members. The situation became too complex for the EU, but this, admittedly, can also be said about other international actors involved in the region who are also unable to stabilize the situation. Critics have pointed out that while the EU's efforts were geared toward achieving a long-term democratic transition and country reconstruction, not enough attention was given to short-term crisis-management planning and the possible use of military instruments. This, coupled with the fact that several Member States - such as Italy, France and the UK undermined the collective action by the EU when they competed with each other to secure contracts for their defence industries, led to unsatisfactory results (Kostanyan and Blockmans, 2014, p.2). The EEAS itself ascribed the lack of success in Libya to a lack of co-ordination between actors involved, leading to overlap, and to 'extremely low absorption capacity' resulting from the lack of political institutions and disagreements on political principles (EEAS, 2014b). The internal document also states that any EU re-involvement is only possible if there is a ceasefire.

The civilian mission EUCAP Sahel Niger launched in 2012 was extended in July for another two years. It was designed to collaborate with the CSDP Capacity Building Mission by providing training to the police, Gendarmerie and Garde Nationale in the country. When setting up the mission, the EU emphasized that it formed part of the comprehensive approach to security and development in the Sahel region.

Crisis management has always been considered a showcase for a comprehensive approach and it is certainly the case that the combination of approaches, including military missions with political and diplomatic actions and development and humanitarian aid, is an important asset. Still, as long as the EU is not willing to invest in its military capacities, it will remain condemned to small-scale and rather short-term missions. This has been all too clear in cases such as Syria and northern Iraq, where it was not the EU but the US taking the lead in the airstrikes against the Islamic State of Iraq and the ash-Sham (ISIS). As noted in a recent review of CSDP by a task force led by the former High Representative Javier Solana: "without a strong military arm, the EU cannot live up to its self-imposed duty to protect security and development, or meet expectations of its citizens and international partners like the United Nations to provide added value by operationalizing its comprehensive approach to conflict prevention, crisis-management and peace-building' (CEPS, 2015, p. 3).

In sum, the increased international instability in 2014 has made the strengths and weaknesses of the EU as a security actor clearer than ever. Although it has over the years built up an important track record in crisis response and reached tangible results in cases such as Operation Atalanta, the EU finds it evidently more difficult to respond to hard security threats such as those posed by jihadi terrorist groups or territorial annexation. It is 
therefore not surprising that in the above-mentioned CEPS report under the chairmanship of Solana (CEPS, 2015, p. 8), CSDP was called 'the weakest link in the European integration project'. When it comes to hard security, the EU continues to be more of a bystander rather than a security provider.

\section{The European Union as a Diplomatic Actor}

The field of diplomacy provides the scene for the third role of the EU in the world. The historical record shows that we could expect some successes here in cases when there is no need for a 'European' army and where the EU's negotiators had been appreciated in the past. Of course, even in this role the EU faced some external limitations, one of which is the nature of international law, which is, in essence, traditional and focused on the role of states (Wessel and Van Vooren, 2013). Another limitation is of a practical nature. The EU may not always be wanted at the negotiation table, paradoxically, as a result of its growing international presence and involvement in the crisis situations. For example, after its initial engagement in the Ukrainian crisis (Ashton had a recognized presence in Kyiv, while the EU was actively involved in the Geneva negotiations in April 2014), from late spring 2014, Russia perceived the EU as a part of the 'problem' rather than an 'honest broker'. Consequently, the political negotiations proceeded in the so-called 'Normandy format' that consists of France, Germany, Russia and Ukraine - but without the EU, while a ceasefire would be negotiated with the engagement of the OSCE.

One of the EU's success stories is that of the negotiations on the Iranian nuclear programme. The outgoing HR/VP Catherine Ashton continued to chair the negotiations with Iran, which were initially scheduled to end in November, but continued for a further seven months (EEAS, 2014a). This created an unusual situation for the European Union, as it was uncertain who would continue fulfilling Ashton's role. Federica Mogherini was already busy in her new role, not least because of the evolving crisis to the east of the EU. Finally, at the end of the year, it was decided that Ashton would stay on as an EU special adviser on the Iranian nuclear talks. Her role was clearly appreciated by all stakeholders, as she kept the information flowing between the main actors involved. After months, even years, of extremely critical media coverage, the first HR/VP received praise in the international press, who called her the 'centre of the world diplomacy'. ${ }^{16}$ She was reportedly greeted with a standing ovation from ambassadors on her return from the October round of negotiations. ${ }^{17}$ This was due to her ability to build up a good relationship with Iranian foreign minister Mohammed Javad Zarif and bring the parties back to the negotiating table in October 2014. It was reportedly Ashton who convinced US secretary of state John Kerry to fly to Geneva in an unprecedented move. Notably, in pursuit of these efforts, the HR/VP even found the time to meet with Iranian women activists in March, spurring a wave of criticism from Iranian officials. Nevertheless, even though the EU was undoubtedly visible and the HR/VP played an important role in facilitating the talks, it was also understood that the crucial players are those outside Europe: the United States, China and Russia.

\footnotetext{
${ }^{16}$ Der Spiegel, 1 October 2013.

${ }^{17}$ Financial Times, 26 November 2014.
} 
The success of the HR/VP personally in her role as a diplomatic actor may be related to the fact that she evidently prioritized this role over the others and that the style of negotiations played exactly into the style she announced at the start of her mandate as "quiet diplomacy'. The success also resulted from long-term efforts into building personal trust and good relationships with all stakeholders involved. One limitation of this approach, however, is that people move on to different positions and there is no assurance of continuity.

\section{Conclusions}

Last year's Annual Review on the relations with the wider world spoke about the anticipated move from chaos to consolidation (Hadfield and Fiott, 2014). Unfortunately, as 2014 showed, this consolidation never happened and the EU was still facing major challenges both in its neighbourhood as well as globally. The year 2014 was the last in the five-year term of the first HR/VP, so we started our contribution with an evaluation of Ashton's legacy. While she was able to set up the new service in a relatively short time span and succeeded in difficult cases such as Iran and the Kosovo-Serbia dossier, it is clear that Ashton did not bring the supranational leadership that many had hoped for. This is, however, only partly the result of her self-perception as a facilitator rather than a leader and the lack of substantial foreign policy background. It is also a result of the reticence on the part of the Member States to create a truly European system of diplomacy where leadership would come from the European level. Although the new HR/VP, by moving to the Commission premises, has given a clear signal that she wanted to tilt the balance in a supranational direction, it remains to be seen whether Mogherini will be able to create a truly collective European diplomacy. The ongoing crisis in the EU's periphery may provide a new chance, but it may also prove an important obstacle as the sense of urgency and the proposed solutions in the different Member States vary widely.

In this contribution, we also analysed the EU's evolving role as a market, security and diplomatic actor in 2014. The ongoing negotiations of a Transatlantic Trade and Investment Partnership with the US and a Bilateral Investment Treaty with China illustrate that the EU continues to be an attractive trading partner for key international players. These bilateral consultations, however, also show that in a changing geo-economic and political context, where power is dispersed, there are several centres, both in the west and the east, with whom the EU wants to develop preferential relations. As a highly integrated market actor, the EU continues to be in a relatively good position to diffuse its internal norms and regulatory rules. However, as the EU-China BIT negotiations illustrate, non-western countries often resist the EU normative standards on human rights and sustainability and we will observe in the future whether a crisis-ridden EU will prioritize values over its eagerness to conquer new markets.

The most important challenges for the EU appeared in its role of a security actor - not so much in the area of crisis management, where it is gradually becoming an established actor, but in the area of defence. The crisis in Ukraine brought home the message that territorial defence continues to matter, even in a post-modern EU. Notwithstanding recent initiatives such as the adoption of a Maritime Security Strategy and an EU Cyber Defence Policy Framework, the EU has not progressed much when it comes to defence issues. As a result of its incapacity to develop its own military capabilities, it remains heavily 
dependent on Nato and more particularly on the US, where the real decisions on the security of the European continent continue to be taken (Techau, 2015). With the instability on the EU's eastern and southern borders, the future shape of the European security architecture, as first discussed in Maastricht in 1991, is fully back on the agenda. Despite more than 20 years of CFSP/CSDP, it still seems more likely that the Americans and Nato, rather than the EU Member States, will remain in charge of guaranteeing the security of the continent.

Finally, this contribution also looked into the question of the EU's capacity to exert diplomatic influence. Here, the signals from the events of 2014 are mixed. While in a crisis such as Ukraine it is still the big Member States, such as Germany and France, who are the key players, the EU's role in the negotiations with Iran showed a respected international interlocutor who is able to make a difference. This success, however, has largely been built on Ashton's persistence and personal skills, which were lost once she left office. Examples presented in this review show that it is still the Member States rather than Brussels who would pick up the phone if third parties were calling (see also Cameron, 2015).

Taking a step back and looking at the overall picture emerging from the EU's response to the numerous external events of 2014, we see, perhaps not surprisingly, that the centre of gravity varies substantively depending on the area of external relations. Despite the Lisbon rhetoric about the abolition of the pillar structure and the single objectives for all dimensions of external action, it is clear that only in the area of external commercial policy does Brussels operate as the real centre of decision-making. In the area of diplomacy and security, the tone is still set by the different national capitals, while in the area of defence it is Washington DC that remains the predominant actor.

\section{References}

Adler-Nissen, R. (2013) 'Symbolic Power in European Diplomacy: the Struggle between National Foreign Services and the EU's External Action Service'. Review of International Studies, Vol. 40, No. 4, pp. 657-81.

Allen, D. and Smith, M. (2010) 'Relations with the Rest of the World'. JCMS, Vol. 48, No. s1, pp. 205-23.

Allen, D. and Smith, M. (2011) 'Relations with the Rest of the World'. JCMS, Vol. 49, No. s1, pp. 209-30.

Balfour, R. and Raik, K. (eds) (2013) The European External Action Service and National Diplomacies, EPC Issue paper No. 73, 8 (Brussels: The EPC).

Barber, T. (2010) 'The Appointments of Herman van Rompuy and Catherine Ashton'. JCMS, Vol. 48, No. s1, pp. 55-67.

Bierbrauer, E. (2014) Negotiations on the EU-Canada Comprehensive Economic and Trade Agreement (CETA) Concluded (Brussels: Directorate for External Relations, European Parliament). Available at «http://www.europarl.europa.eu/thinktank/en/document.html?refer ence=EXPO_IDA(2014)536410» Accessed 4 June 2015.

Blockmans, S. (2014) Priorities for the Next Legislature: EU External Action, CEPS Commentary (Brussels: Centre for European Policy Studies).

Cameron, F. (2015) 'Concluding Remarks'. In Smith, M., Keukeleire, S. and Vanhoonacker, S. (eds) The Diplomatic System of the European Union: Evolution, Change and Challenges (London and New York: Routledge). 
Carnegie Europe (2014) Judy Asks: Can Tusk Boost Europe's Foreign Policy? Available at «carnegieeurope.eu/strategiceurope/?fa=57368»

CEPS (2015) Report of a CFSP Task Force: More Union in European Defence (Brussels: CEPS).

Council of the EU (2003) A Secure Europe in a Better World. European Security Strategy Brussels.

Council of the EU (2010) 'Council decision of 26 July establishing the organization and functioning of the European External Action Service', 2010/427/EU, 2010, OJ L201/30-40.

Duke, S. and Vanhoonacker, S. (2016, forthcoming) 'EU-NATO Relations: Top-down Strategic Paralysis, Bottom-up Cooperation'. In Chappell, L., Mawdsley, J. and Petrov, P. (eds) The EU, Strategy and Security Policy (London and New York: Routledge).

Edwards, G. (2013) 'The EU Foreign Policy in the Search for Effect'. International Relations, Vol. 27, No. 3, pp. 276-91.

EEAS (2013) EU-China 2020 Strategic Agenda for cooperation (Brussels: EEAS). Available at «http://eeas.europa.eu/china/docs/20131123_agenda_2020_en.pdf» Accessed 4 June 2015.

EEAS (2014a) Joint Statement by Catherine Ashton and Iranian Foreign Minister Mohammad Javad Zarif following the talks in Vienna, 24 November 2014. Available at «http://eeas.europa.eu/statements-eeas/2014/141124_02_en.htm» Accessed 4 June 2015.

EEAS (2014b) Libya, a Political Framework for a Crisis Approach. Cover Note, Brussels 1 October 2014, 13829/14.

European Commission (2013) Joint Communication to the European Parliament and the Council; The EU's Comprehensive approach to external conflicts and crises. Available at «http://www. eeas.europa.eu/statements/docs/2013/131211_03_en.pdf» Accessed 4 June 2015.

European Commission (2014a) Trade and Investment 2014 (Luxembourg: Publications Office of the European Union).

European Commission (2014b) Public Opinion in the European Union. First Results. Standard Eurobarometer 82. Available at «http://ec.europa.eu/public_opinion/archives/eb/eb82/ eb82_first_en.pdf» Accessed 4 June 2015.

European Commission (2014c) President Juncker's Mission Letter to Federica Mogherini, 1 November. Available at «http://ec.europa.eu/commission/sites/cwt/files/commissioner_mission_letters/ mogherini_en.pdf» Accessed 4 June 2015.

European Council (2013) Conclusions, Brussels, 20 December 2013. Available at «http://www. eca.europa.eu/Lists/ECADocuments/SR14_11/SR14_11_EN.pdf» Accessed 4 June 2015.

European Council on Foreign Relations (2015) European Foreign Policy Scoreboard 2015 (London: ECFR).

European Court of Auditors (2014) Special Report: The Establishment of the European External Action Service, No. 11, Luxembourg. Available at «http://www.eca.europa.eu/Lists/ ECADocuments/SR14_11/SR14_11_EN.pdf» Accessed 4 June 2015.

European Parliament (2013) The Maritime Dimension of CSDP: Geostrategic Maritime Challenges and Their Implications for the European Union, Directorate-General for External Policies of the European Union. Available at «http://www.europarl.europa.eu/RegData/etudes/ etudes/join/2013/433839/EXPO-SEDE_ET(2013)433839_EN.pdf» Accessed 4 June 2015.

Frontini, A. (2014) The European Union Maritime Security Strategy: Sailing Uncharted Waters? CEPS. Available at «http://www.epc.eu/pub_details.php?pub_id=4569» Accessed 4 June 2015.

Hadfield, A. and Fiott, D. (2014) 'Relations with the Rest of the World: From Chaos to Consolidation?'. JCMS, Vol. 52, No. s1, pp. 170-85.

Howorth, J. (2011) 'The "New Faces" of Lisbon: Assessing the Performance of Catherine Ashton and Herman van Rompuy on the Global Stage'. European Foreign Affairs Review, Vol. 16, No. 3, pp. 303-23.

Kissinger, H. (2014) World Order (London: The Penguin Press). 
Korteweg, R. (2015) 'It's the Geopolitics Stupid: Why TTIP Matters'. Centre for European Reform, 2 April 2015. Available at «http://www.cer.org.uk/insights/it's-geopolitics-stupid-whyttip-matters»

Kostanyan, G. and Blockmans, S. (2014) Saving Libya from Itself: What the EU Should Do Now. CEPS Commentary, 1 December 2014.

Maurer, H. and Raik, K. (2014) Pioneers of a European Diplomatic System, FIIA Analysis no. 1.

McGuire, S. and Lindeque, J. (2010) 'The Diminishing Returns to Trade Policy in the European Union'. Journal of European Public Policy, Vol. 17, No. 5, pp. 1329-49.

Menon, A. (2014) 'The JCMS Annual Review Lecture: Divided and Declining? Europe in a Changing World'. JCMS, Vol. 52, No. s1, pp. 5-24.

Meunier, S. (2014) 'Divide and Conquer? China and the Cacophony of Foreign Investment Rules in the EU'. Journal of European Public Policy, Vol. 21, No. 7, pp. 996-1016.

Meunier, S. and Nicolaidis, K. (2011) 'The European Union as a Trade Power'. In Hill, C. and Smith, M. (eds) International Relations and the European Union (Oxford: Oxford University Press).

North Atlantic Council (2014) Wales Summit Declaration Issued by the Heads of State and Government participating in the meeting of the North Atlantic Council in Wales, 5 September. Available at «http://www.nato.int/cps/ic/natohq/official texts_112964.htm» Accessed 4 June 2015.

Novotna, T. (2014) 'The EU's Voice in Third Countries. The EU Delegations around the World'. Studia Diplomatica, Vol. 67, No. 1, pp. 29-45.

Smith, M. (2012) 'Still Rooted in Maastricht: EU External Relations as a "Third-generation Hybrid"'. Journal of European Integration, Vol. 34, No. 7, pp. 699-715.

Smith, M.E. (2013) 'The European External Action Service and the Security-Development Nexus: Organizing for Effectiveness or Incoherence?' Journal of European Public Policy, Vol. 20, No. 9, pp. 1299-315.

Smith, M. (2015) 'The EU and China: The Politics and Economics of Strategic Diplomacy'. In Smith, M., Keukeleire, S. and Vanhoonacker, S. (eds) The Diplomatic System of the European Union: Evolution, Change and Challenges (London and New York: Routledge).

Spence, D. (2012) 'The Early Days of the European External Action Service: A Practitioners' View'. The Hague Journal of Diplomacy, Vol. 7, No. 1, pp. 115-34.

Techau, J. (2015) European Security After Ukraine. Carnegie Europe. Available at «http:// carnegieeurope.eu/strategiceurope/?fa=59025» Accessed 4 June 2015.

Ulgen, S. (2014) Locked in or Left out? Transatlantic trade beyond Brussels and Washington, Carnegie Europe. Available at: «http://carnegieeurope.eu/2014/06/03/locked-in-or-left-outtransatlantic-trade-beyond-brussels-and-washington/hcf1» Accessed 4 June 2015.

Vanhoonacker, S. and Pomorska, K. (2015) 'EU Diplomacy Post-Lisbon: The Legacy of the Ashton Era'. In Smith, M., Keukeleire, S. and Vanhoonacker, S. (eds) The Diplomatic System of the European Union: Evolution, Change and Challenges (London and New York: Routledge).

Vanhoonacker, S. and Pomorska, K. (2013) 'The European External Action Service and agendasetting in European Foreign Policy'. Journal of European Public Policy, Vol. 20, No. 9, pp. 1316-31.

Van Schaik, L. and Ter Haar, B. (2013) 'Why the EU is Not Promoting Effective Multilateralism. On a Fundamental Flaw in the European Security Strategy', Clingendael Policy Brief, No. 21, June.

Wessel, R. and Van Vooren, B. (2013) 'The EEAS' Diplomatic Dreams and the Reality of European and International Law'. Journal of European Public Policy, Vol. 20, No. 9, pp. 1350-67.

Wright, N. (2013) 'Co-operation, Co-optation, Competition? How do Britain and Germany Interact with the European External Action Service?' Paper presented at the 43rd UACES Annual Conference, University of Leeds, UK, 2-4 September. 